\title{
Threshold values for mould growth: Critical moisture level of 21 different building materials
}

\author{
Pernilla Johansson ${ }^{1, *}$, Lukas Lång ${ }^{1}$, Gunilla Bok $^{1}$, and Carl-Magnus Capener ${ }^{1}$ \\ ${ }^{1}$ RISE Research Institutes of Sweden, Built Environment, Box 857, S50115 Borås, Sweden
}

\begin{abstract}
The susceptibility for mould growth varies among different building materials. One way to describe the susceptibility is the lowest RH at which mould can grow on a specific material, the critical moisture level (RHcrit). Determining RHcrit for materials provide the basis for material choice in designs where moisture and temperature conditions are known. In this study, RHcrit of 21different products were determined according to SIS-TS 41:2014/SPMet 4927. This test method is developed based on the results of a variety of laboratory studies and validated by field studies. Test specimens were inoculated with a suspension containing spores from six different mould fungi and were then incubated in moisture chambers at four levels of RH at $22{ }^{\circ} \mathrm{C}$. After 12 weeks specimens were analysed for mould growth. RHcrit was determined based on the lowest RH at which mould grew on the specimens. RHcrit varied among different products, even between product belonging to a similar group of material, for example, calcium silicate boards or gypsum boards. The results show, and confirm, previous findings that it is not possible to estimate RHcrit for a specific product based on material group. Instead, each product must be tested.
\end{abstract}

\section{Introduction}

The susceptibility for mould growth varies among different building materials, depending on nutrient content, $\mathrm{pH}$, surface structure, additives etc. One way to describe the susceptibility is the critical moisture value for mould growth, $\mathrm{RH}_{\text {crit, }}$, the lowest relative humidity $(\mathrm{RH})$ at which mould can grow on a material.

$\mathrm{RH}_{\text {crit }}$ is temperature-dependent; at a higher temperature, $\mathrm{RH}_{\text {crit }}$ is lower. The values can be described for a range of temperatures, as isopleths. Two examples are shown in Figure 1.

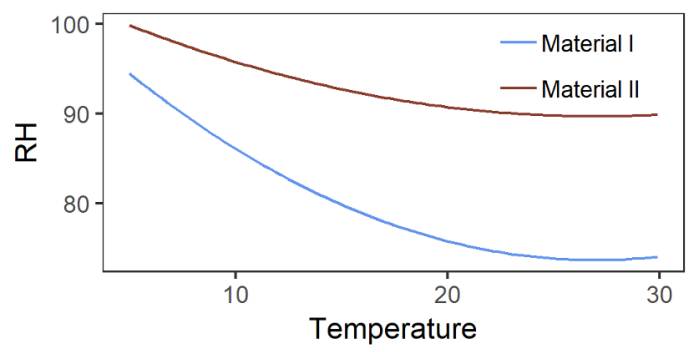

Fig. 1. Two examples of $\mathrm{RH}_{\text {crit }}$ of two hypothetic materials at different temperatures

One way of preventing the growth of mould in buildings is therefore to choose building materials that can withstand the expected conditions, i.e. materials with a higher critical moisture level than the highest expected RH. It is thus crucial that data are available to allow the correct choice of materials to be made.

\footnotetext{
*Corresponding author: pernilla.johansson@ri.se
}

It has previously been stated that it may be difficult, or even impossible, to estimate the $\mathrm{RH}_{\text {crit }}$ for a specific material based on the results from tests of other products made of similar materials, for example, wood-based boards[1]. In that study, ten different building materials were tested, and a few material classes were represented. The study presented in this paper aimed to determine $\mathrm{RH}_{\text {crit }}$ for other products. Some of those belongs to the same material group, for example, gypsum boards. The materials consisted of different products commercially used in Europe in internal insulation systems. The study was part of the Horizon 2020 project RIBuild (Robust Internal Thermal Insulation of Historic Buildings).

\section{Materials and methods}

\subsection{Building materials}

The partners in the RIBuild project were asked to select products used for internal insulation in their respective country. Some of the products have been used in other field or laboratory tests in RIBuild. Samples of products, clean and unused, were sent to the laboratory at one of the partners for testing. The samples were packaged with diffusion open wrapping to avoid mould growth during transport and were also dry and clean before being wrapped.

At the laboratory, the samples of board materials were divided into test specimens, size $50 \times 100 \mathrm{~mm}$. Test specimens of loose-fill insulation were prepared by 
placing the material in a cage of fine stainless-steel mesh (autoclaved) with an internal volume of approximately 0.05 litres per specimen. Seven different mortar mixes were tested. The mortars were prepared from raw powder according to the instructions for each product. The mixture was then partitioned in Petri dishes with a diameter of $90 \mathrm{~mm}$. The thickness of each sample was approximately $7-10 \mathrm{~mm}$. The tested products of board materials and the loose-fill insulation are shown in Figure 2.

In some cases, the product consists of two or three different material layers. In those cases, each side was evaluated separately. In Figure 3, the tested mortars are shown.
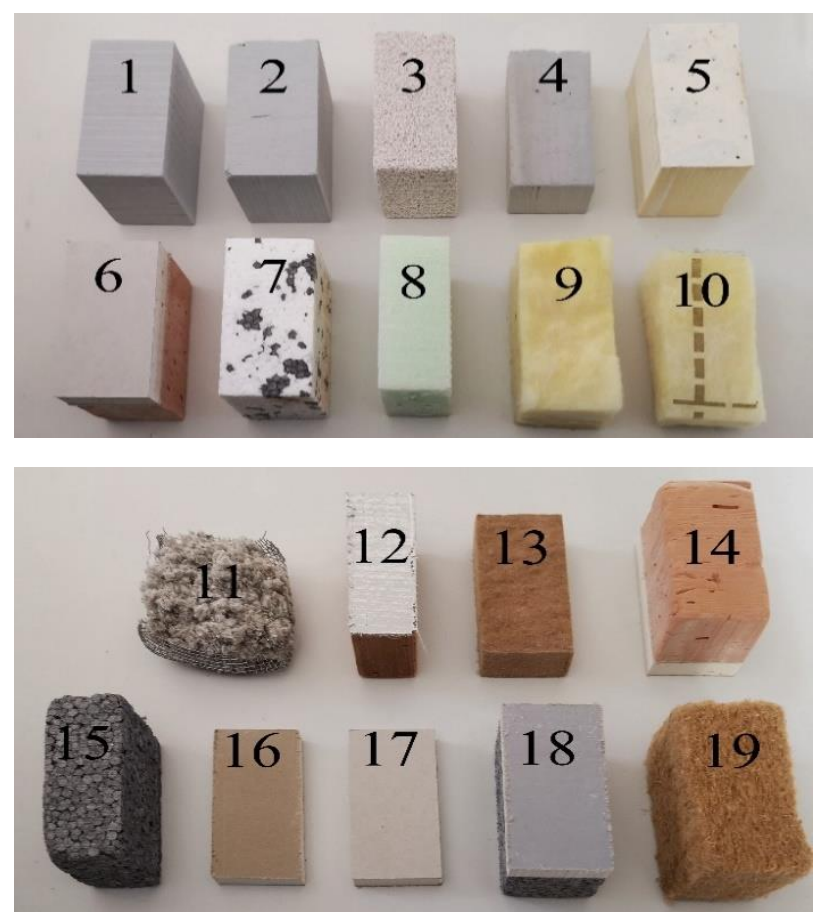

Fig. 2. The building materials tested. The numbers refer to the material name presented in Table 1. Note that there may be two different sides/faces of the same product.

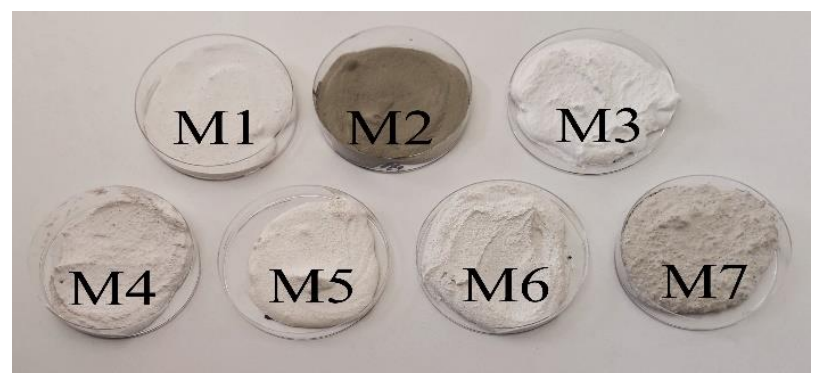

Fig. 3 The tested mortars.
Table 1. Materials referred to in Figure 2. Specimens belonging to same product is marked with the same lowercase letters.

\begin{tabular}{|c|c|c|c|}
\hline Number & Description & Number & Description \\
\hline $1-4$ & $\begin{array}{l}\text { Calcium } \\
\text { silicate board }\end{array}$ & $12^{\mathrm{a}}$ & $\begin{array}{l}\text { Foil-scrim } \\
\text { facer on PUR }\end{array}$ \\
\hline 5 & $\begin{array}{l}\text { Polyurethane } \\
\text { foam (PUR) }\end{array}$ & 13 & $\begin{array}{l}\text { Cellulose } \\
\text { fibre } \\
\text { insulation } \\
\text { board }\end{array}$ \\
\hline $6^{\mathrm{a}}$ & Gypsum board & $14^{\mathrm{a}}$ & $\begin{array}{l}\text { Polyurethane } \\
\text { foam (PUR) }\end{array}$ \\
\hline 7 & $\begin{array}{l}\text { Polystyrene } \\
\text { board }\end{array}$ & $15^{\mathrm{c}}$ & $\begin{array}{l}\text { Polystyrene } \\
\text { board }\end{array}$ \\
\hline 8 & $\begin{array}{l}\text { Polystyrene } \\
\text { board }\end{array}$ & $16-17$ & $\begin{array}{l}\text { Gypsum } \\
\text { board, two } \\
\text { sides of the } \\
\text { same products }\end{array}$ \\
\hline $9^{b}$ & $\begin{array}{l}\text { Mineral wool } \\
\text { board }\end{array}$ & $18^{\mathrm{c}}$ & $\begin{array}{l}\text { Gypsum } \\
\text { board }\end{array}$ \\
\hline $10^{\mathrm{b}}$ & $\begin{array}{l}\text { Soft tissue on } \\
\text { mineral wool } \\
\text { board }\end{array}$ & 19 & $\begin{array}{l}\text { Cellulose } \\
\text { fibre } \\
\text { insulation } \\
\text { board }\end{array}$ \\
\hline 11 & $\begin{array}{l}\text { Cellulose fibre } \\
\text { loose-fill } \\
\text { insulation }\end{array}$ & & \\
\hline
\end{tabular}

\subsection{Method}

The test was performed according to the test method "Laboratory method for assessment of the lowest hygrothermal conditions required for mould growth", also called the CML method (Critical Moisture Level method)[2, 3]. It is based upon different standardised methods for determining the mould resistance of building materials (performed at high $\mathrm{RH}$ ) and on extensive laboratory testing of mould growth on many building materials in different $\mathrm{RH}$ and temperatures[1]. The method has been validated by field studies in buildings[4]. In the Swedish National Board of Housing, Building and Planning (Boverket) building regulations (BBR) it says that the "Critical moisture levels shall be used to determine the maximum permitted moisture level [5].The method used in this paper is referred to as a possible test method.

Seven test specimens of each material in Figure 2 and three specimens of each mortar to be tested were exposed to spores of mould fungi, by spraying them with a spore suspension. Then, they were placed in moisture chambers at four different RH levels favourable for mould growth and were after 12 weeks analysed for any growth at the surface. 
The method provides routines to ensure the reproducibility. Among these routines are procedures for the preparation and inoculation of spore suspension on test specimens, incubation conditions (including specifications for the test chamber), handling of test specimens and assessment of growth on the test pieces. Also, there are instructions for the action to be taken if deviation occurs.

In [6], the method is described and discussed to give an understanding of the routines and principles of the method.

\subsubsection{Spore inoculation}

A water suspension was prepared under sterile conditions, containing spores from six common mould fungi; Eurotium herbariorum (CBS 115808), Aspergillus versicolor (CBS 117286), Penicillium rubens (CBS 401.92), Aureobasidium pullulans (CBS 101160), Cladosporium sphaerospermum (CBS 122.63) and Stachybotrys chartarum (CBS 109292). The concentration of spores was counted, diluted and mixed to $10^{6}$ spores per $\mathrm{ml}$ of each species in the solution. $0.4 \mathrm{ml}$ of the spore suspension was sprayed evenly onto one surface of each test specimen.

\subsubsection{Incubation in moisture chambers}

Following the inoculation of spores, the test specimens were incubated horizontally in four different climate test chambers (CTS C-20/350, CTS GmbH, Hechningen, Germany) for 12 weeks. The inoculated side of the specimen was faced up. The set RH in the chambers was $80 \%, 85 \%, 90 \%$ and $95 \%$ respectively. The temperature was $22^{\circ} \mathrm{C}$. Air with the desired $\mathrm{RH}$ and temperature streamed over the test pieces at a velocity of $0.3-0.5 \mathrm{~m} / \mathrm{s}$, which ensured that the microclimate at the surface of each test specimen was the same. Temperature and $\mathrm{RH}$ in each chamber were continuously measured by calibrated integrated capacitive sensors and saved digitally with a software (CID-pro).

\subsubsection{Mould analysis}

After 12 weeks, test specimens were removed from the chambers and analysed under a microscope at 10-40x magnification. Mould growth on the inoculated surface of each test sample, excluding the edges, was assessed according to a five-point rating scale, see Table 2 .

Although there may be extensive growth on a material, it is often not seen by the naked eye. Not all species have dark pigments in their cells, and the pigmentation can vary due to environmental conditions, nutrients in the substrate and phase in the lifecycle of the fungus. Also, the discolouration is perceived differently, depending on the contrast with the underlying colour of the surface. Therefore, both mould growth visible to the naked eye and growth only visible under the microscope was studied.
Table 2. Rating scale for the assessment of mould growth

\section{Rating Description of Schematic illustration extent of growth}

0

$$
\begin{aligned}
& \text { No mould } \\
& \text { growth. }
\end{aligned}
$$

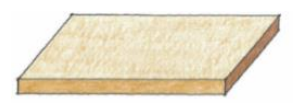

1

Initial growth; one or a few hyphae and no conidiophores.

2

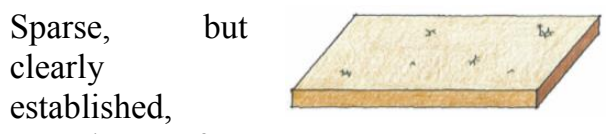

growth; often conidiophores are beginning to develop.

$$
\begin{aligned}
& \text { Patchy, heavy } \\
& \text { growth with } \\
& \text { many well- } \\
& \text { developed } \\
& \text { conidiophores. }
\end{aligned}
$$

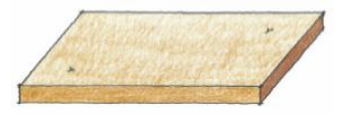

Heavy growth over more or less the entire surface.
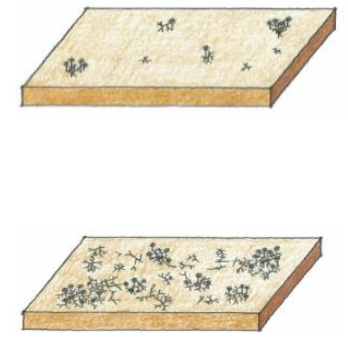

${ }^{1}$ Note that the pictures are only schematic for guidance and that the growth may not be visible to the naked eye.

\subsection{Determination of $\mathrm{RH}_{\text {crit }}$ at $22^{\circ} \mathrm{C}$}

$\mathrm{RH}_{\text {crit }}$ was determined by considering the lowest $\mathrm{RH}$ at which mould growth was established on the test specimens and the next lower RH where no growth was detected during analysis. The actual critical moisture level was then considered to be somewhere between these two values, or at the $\mathrm{RH}$ when the test pieces failed. The principle is illustrated in Figure 4. For example, if there was no mould growth on a material at $80 \%$ or $85 \% \mathrm{RH}$ after 12 weeks testing, and there was growth at $90 \%$, and $95 \% \mathrm{RH}$, the result was $\quad 85 \%<R H_{\text {crit }} \leq 90 \%$ (Figure $4 \mathrm{a}$ ). Mould growth was defined as rating equal to or exceeding 2 of at least two of the seven test pieces in the specific RH.

The tested materials are classified to belong to one out of five different groups, based on $\mathrm{RH}_{\text {crit, }}$, see Table 3 . 
Table 3 Description of material classes, based on $\mathrm{RH}_{\text {crit. }}$

\begin{tabular}{|l|l|}
\hline Class & $\mathbf{R H}_{\text {crit }}$ at $2{ }^{\circ} \mathbf{C}$ \\
\hline Class A & $75 \% \leq \mathrm{RH}_{\text {crit }} \leq 80 \%$ \\
\hline Class B & $80 \%<\mathrm{RH}_{\text {crit }} \leq 85 \%$ \\
\hline Class C & $85 \%<\mathrm{RH}_{\text {crit }} \leq 90 \%$ \\
\hline Class D & $90 \%<\mathrm{RH}_{\text {crit }} \leq 95 \%$ \\
\hline Class E & $\mathrm{RH}_{\text {crit }}>95 \%$ \\
\hline
\end{tabular}

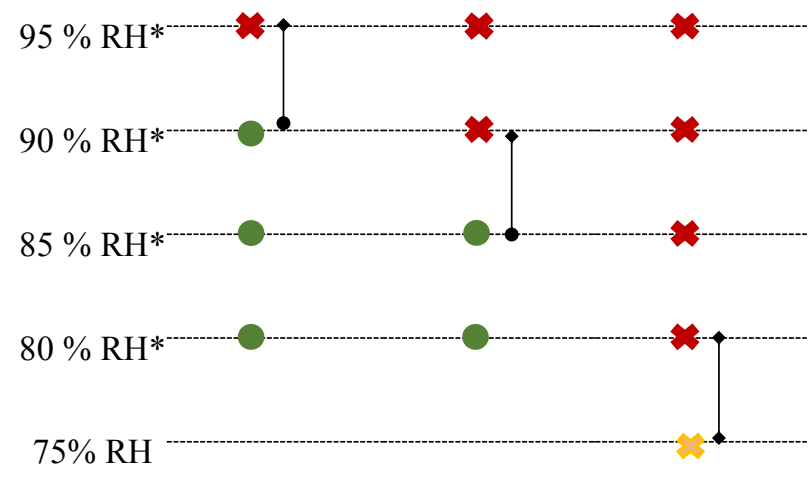

(a)

(b)

(c)

Fig. 4. Principle of determination of critical moisture level, three examples. The numbers of $\mathrm{RH}$ with an asterisk represent the tested RH. Green circle represents cases where there was no growth in that RH on the tested material, while a red cross represents cases with growth. In example (a), there is mould growth at $95 \% \mathrm{RH}$ but not at any other $\mathrm{RH}$ hence $90 \%<\mathrm{RH}_{\text {crit }}$ $\leq 95 \%$. In example (b) there is growth at $95 \%$ and $90 \%$, while there is no growth at lower RH. Therefore; $90 \%<\mathrm{RH}_{\text {crit }} \leq 85 \%$. In example (c) there is growth on the test specimens at all tested $\mathrm{RH}$. Although not tested, $75 \%$ is considered the lowest limit for mould growth (based on literature and our testing in other study) and marked with a yellow cross as mould may be possible. The critical moisture level is established as $75 \% \leq \mathrm{RH}_{\text {crit }} \leq 80 \%$.

\subsubsection{Control of incubation $\mathrm{RH}$ and temperature}

At the end of the test period (12 weeks) the mean, standard deviation and measurement uncertainties, according to EA-4/02, of RH and temperature in each chamber was calculated.

The method aims to find the critical moisture level for mould growth on a material. Therefore, it is essential to control the values of $\mathrm{RH}$ at which the test has been performed. The precise mean RH and temperature that the specimens are exposed to will never be precisely the set values, due to the expanded measurement uncertainties. These are caused, for example, by variation in each chamber and by measurement error from calibration of the sensors.

In the test method, there are specified limits, $\pm 2.5 \%$ of each of the set values for $\mathrm{RH}$ and $\pm 2{ }^{\circ} \mathrm{C}$ for the temperature. To distinguish the different incubation $\mathrm{RH}$ from each other, the mean value together with the measurement uncertainties must fall within these limits. The procedure is illustrated in Figure 5.

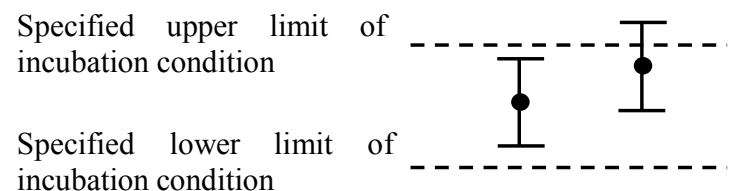

(a)

(b)

Fig. 5 Illustration of the evaluation of incubation criteria. The dots represent mean measured values of RH or temperature and the whiskers represent the calculated expanded uncertainty. In (a) the mean value with uncertainties fall into allowed limits. In (b) it does not, since the upper limit is exceeded. Therefore, in this case, the test is not valid.

\section{Results and discussion}

All controls for the incubation temperature and $\mathrm{RH}$ fulfilled the criteria, and therefore the tests were valid. The results, $\mathrm{RH}_{\text {crit }}$, are shown in Table 4 and Table 5.

Table 4 Results from the test of mortars.
\begin{tabular}{|l|l|l|}
\hline Nr & Class & RH $_{\text {crit }}(\%)$ \\
\hline M1 & D & $90>\mathrm{RH}_{\text {crit }} \leq 95$ \\
\hline M2 & D & $90>\mathrm{RH}_{\text {crit }} \leq 95$ \\
\hline M3 & E & $\mathrm{RH}_{\text {crit }}>95$ \\
\hline M4 & E & $\mathrm{RH}_{\text {crit }}>95$ \\
\hline M5 & D & $90>\mathrm{RH}_{\text {crit }} \leq 95$ \\
\hline M6 & E & $\mathrm{RH}_{\text {crit }}>95$ \\
\hline M7 & E & $\mathrm{RH}_{\text {crit }}>95$ \\
\hline
\end{tabular}


Table 5 Results from the test. "Nr" refers to the number in Figure 2 and Class to Table 3

\begin{tabular}{|c|c|c|c|}
\hline $\mathrm{Nr}$ & Class & $\mathrm{RH}_{\text {crit }}(\%)$ & Group \\
\hline 1 & $\mathrm{D}$ & $90>\mathrm{RH}_{\text {crit }} \leq 95$ & $\begin{array}{l}\text { Calcium silicate } \\
\text { board }\end{array}$ \\
\hline 2 & $\mathrm{E}$ & $\mathrm{RH}_{\text {crit }}>95$ & $\begin{array}{l}\text { Calcium silicate } \\
\text { board }\end{array}$ \\
\hline 3 & $\mathrm{D}$ & $90>\mathrm{RH}_{\text {crit }} \leq 95$ & $\begin{array}{l}\text { Calcium silicate } \\
\text { board }\end{array}$ \\
\hline 4 & $\mathrm{D}$ & $90>\mathrm{RH}_{\text {crit }} \leq 95$ & $\begin{array}{l}\text { Calcium silicate } \\
\text { board }\end{array}$ \\
\hline 5 & $\mathrm{D}$ & $90>\mathrm{RH}_{\text {crit }} \leq 95$ & $\begin{array}{l}\text { Polyurethane foam } \\
\text { (PUR) }\end{array}$ \\
\hline 6 & $\mathrm{D}$ & $90>\mathrm{RH}_{\text {crit }} \leq 95$ & Gypsum board \\
\hline 7 & $\mathrm{E}$ & $\mathrm{RH}_{\text {crit }}>95$ & Polystyrene board \\
\hline 8 & E & $\mathrm{RH}_{\text {crit }}>95$ & Polystyrene board \\
\hline 9 & $\mathrm{D}$ & $90>\mathrm{RH}_{\text {crit }} \leq 95$ & Mineral wool \\
\hline 10 & $\mathrm{E}$ & $\mathrm{RH}_{\text {crit }}>95$ & Mineral wool \\
\hline 11 & E & $\mathrm{RH}_{\text {crit }}>95$ & Cellulose fibre \\
\hline 12 & $\mathrm{C}$ & $85>\mathrm{RH}_{\text {crit }} \leq 90$ & Aluminum foil \\
\hline 13 & $\mathrm{~A}$ & $75>\mathrm{RH}_{\text {crit }} \leq 80$ & Cellulose fibre \\
\hline 14 & $\mathrm{E}$ & $\mathrm{RH}_{\text {crit }}>95$ & $\begin{array}{l}\text { Polyurethane foam } \\
\text { (PUR) }\end{array}$ \\
\hline 15 & E & $\mathrm{RH}_{\text {crit }}>95$ & Polystyrene board \\
\hline 16 & $\mathrm{D}$ & $90>\mathrm{RH}_{\text {crit }} \leq 95$ & Gypsum board \\
\hline 17 & $\mathrm{D}$ & $90>\mathrm{RH}_{\text {crit }} \leq 95$ & Gypsum board \\
\hline 18 & $\mathrm{C}$ & $85>\mathrm{RH}_{\text {crit }} \leq 90$ & Gypsum board \\
\hline
\end{tabular}

\section{Discussion}

$\mathrm{RH}_{\text {crit }}$ varied among the different products included in this study. Conventional tests for mould resistance are performed at high RH, generally above $95 \%$. Many of the products in this study would have failed such a test. However, a product not fulfilling the mould resistance test, could still be used in building parts were the RH are not expected to be as high, with expected low risk for mould growth.

The results confirm the previous conclusion [1] that it is not possible to predict $\mathrm{RH}_{\text {crit }}$ for one specific product from the result from another product belonging to the same group of materials. For example, different boards of calcium silicate in the study belong to two different classes of $\mathrm{RH}_{\text {crit }}$ (class D or class E). The gypsum boards tested belong to two different classes of $\mathrm{RH}_{\text {crit, }}$ (class $\mathrm{C}$ or class D) as did the products based on cellulose fibres (class A or E).

Even two different sides of the same product may have different $\mathrm{RH}_{\text {crit, }}$ as in this case, the mineral wool fibreboard, nr 9 and 10 in Figure 2. The different mortars tested belonged to either class D or class $\mathrm{E}$.

During production, different batches of a product may vary in their quality that possibly can affect $\mathrm{RH}_{\text {crit. }}$. Therefore, the test method used in this study prescribes that test samples should be "preferably from different batches in production. It is particularly important if the quality is expected to vary between batches." In this study, RIBuild partners were asked to send materials from different boards of the same product. However, it is suspected that, in most cases, the board samples of a specific product belong to the same board. If there were samples from different boards, there is no traceability, and it is not possible to identify if they come from different batches. The results from the study are therefore valid for the specific samples tested, and there might be different results if the same product from another batch are tested.

Contamination of the materials with dirt etc. may affect the susceptibility for mould growth. At the laboratory, the specimens were handled with clean gloves. When selecting and sending the materials to the laboratory, partners had previously been asked to handle the samples to minimise the risk for contamination. However, it cannot be ensured that they were clean. However, as seven samples from each product was used for each RH tested, the possible risk of contamination affecting the results was reduced.

As stated in the introduction, $\mathrm{RH}_{\text {crit }}$ also varies depending on temperature. $\mathrm{RH}_{\text {crit }}$ reported in this paper is valid for $22^{\circ} \mathrm{C}$. In the method, $\mathrm{RH}_{\text {crit }}$ is also assessed for other temperatures by using an equation, based on Sedlbauers LIMcurves and extensive testing of mould growth on different temperatures and RH [1]. If calculations are repeated for a series of temperatures typical in buildings, the critical moisture levels can be expressed as growth limit curves.

\section{Conclusions}

The results verify previous findings that mould susceptibility, in this study determined as $\mathrm{RH}_{\text {crit, }}$ cannot be estimated based on which group of material it belongs to, supposed contents of organic compounds or chemical additives. Instead, each product must be tested.

Even different faces of a material may vary in susceptibility for mould growth. If a product has two different facings, each facing should be tested separately. Also, all individual components of a composite product should be tested.

Testing of $\mathrm{RH}_{\text {crit }}$ widens the use of materials compared with mould resistance test that only evaluates the resistance to mould growth in a "worst-case scenario", i.e. at levels limited to relatively high $\mathrm{RH}$ and temperature. 


\section{References}

1. P. Johansson, A. Ekstrand-Tobin, $T$. Svensson,G. Bok, Int. Biodeterior. Biodegrad. 73,(2012)

2. SP Technical Research Institute of Sweden.SP Method 4927. Laboratory Test Method for Determining Critical Moisture Level for Mould Growth on Building Materials.(2012)

3. SIS Swedish Standards Institute.SIS-TS 41:2014 Building materials - Laboratory method for assessment of the lowest hygrothermal conditions required for mould growth.(2014)

4. P. Johansson, T. Svensson,A. Ekstrand-Tobin, Build Environ 62,(2013)

5. B.a.P. Boverket Swedish National Board of Housing.(2014)

6. P. Johansson, A. Ekstrand-Tobin,G. Bok, Build Environ 81,(2014) 